\title{
Potensi Korupsi dalam Kebijakan Publik Studi Kasus Korupsi Program Penanganan Sosial Ekonomi Masyarakat di Provinsi Jawa Timur
}

\author{
Nian Riawati
}

\begin{abstract}
Socio-Economic Community Treatment Program (P2SEM) is one of the local government policy interventions to avoid social contraction after the rise of fuel prices. Unfortunately, this policy was not well-implemented by East Java Provincial Government although Local Legislative has made approval for the implementation. This study employs case study methods in order to focus more on the corruption practice of this policy since it first implementation until fund distribution to the target group.
\end{abstract}

\section{Keywords:}

policy; corruption; Legislative and Executive.

\begin{abstract}
Abstrak
Program Penanganan Sosial Ekonomi Masyarakat (P2SEM) merupakan salah satu intervensi kebijakan untuk menghindari adanya kontraksi sosial pasca kenaikan harga BBM. Namun, dalam implementasinya, kebijakan ini dapat dikategorikan sebagai kebijakan koruptif yang diambil bersama antara Pemerintah Provinsi Jawa Timur dengan Dewan Perwakilan Rakyat Provinsi Jawa Timur. Studi kasus menjadi pilihan dalam penelitian ini dengan tujuan untuk menganalisa secara lebih mendalam terkait kasus korupsi P2SEM yang dimulai sejak awal program ini dilahirkan hingga tahap penyaluran dana kelompok pelaksana dan kelompok sasaran program.
\end{abstract}

\section{Kata kunci:}

kebijakan; korupsi; Legislatif dan Eksekutif.

\section{Pendahuluan}

Gerakan reformasi telah menjadi pendulum pergeseran kekuatan dari birokrasimiliter kepada kekuatan civil society. Pergeseran kekuasaan ini ditandai dengan terpilihnya KH. Abdurrahman Wahid dan Megawati Soekarnoputri sebagai Presiden dan Wakil Presiden yang dipilih secara demokratis oleh Sidang Istimewa MPR RI. Tidak hanya itu, gerak reformasi juga telah memulihkan kekuasaan lembaga Legislatif sebagai lembaga legislasi maupun lembaga kontrol, hal ini demi terciptanya check and balances dalam relasi ketatanegaran Indonesia. Dalam perjalanannya, perubahan pola kekuasaan ini juga menggeser bandul korupsi dari birokrasi menuju lembaga Legislatif.

Hasil survei Kemitraan tentang peringkat korupsi lembaga negara memperlihatkan,

- Dosen Universitas Jember

Email: nian.faezya@gmail.com 
lembaga Legislatif menempati urutan nomor satu sebagai lembaga terkorup dibandingkan lembaga Yudikatif dan Eksekutif. Hasil survei tersebut menyebutkan korupsi Legislatif sebesar 78 persen, Eksekutif 32 persen dan Yudikatif 70 persen. Survei ini dilakukan pada 2010 dengan metode targetted (meminta pendapat orang tertentu yang berkompeten untuk menilai di lembaga masing-masing) dan dilakukan di 27 provinsi di Indonesia. ${ }^{1}$ Sedangkan berdasarkan survei tahun 2006 yang dilakukan oleh Transparency International Indonesia (TII), sebuah lembaga yang aktif menentang praktik korupsi. Dalam skala satu hingga lima, DPR memperoleh skor 4,2 poin sehingga menjadi lembaga terkorup di Indonesia. ${ }^{2}$ Sebelumnya, tahun 2005 TII juga mengumumkan hasil survei bahwa lembaga terkorup di Indonesia ditempati partai politik yang notabene adalah "rumah" para elit politik kita, baik elit politik di lembaga Eksekutif maupun Legislatif. Harus diakui, bahwa bandul korupsi telah benar-benar bergeser dari birokrasi menuju lembaga Legislatif dan partai politik.

Penelitian ini bertujuan mengkaji praktek korupsi yang terjadi dalam Program Penanganan Sosial Ekonomi Masyarakat (P2SEM). Studi ini sangat penting untuk kajian korupsi, karena akan melihat dan mempelajari lebih jauh modus dan pola-pola korupsi dari latar belakang program tersebut mulai diputuskan hingga terjadinya kasus korupsi.

Penelitian ini di lakukan di Provinsi Jawa Timur dengan melihat dan menganalisis perkembangan kasus-kasus P2SEM pada beberapa LSM yang terkena kasus korupsi yang terjadi hampir di seluruh kabupaten di Jawa Timur. Hasil pemeriksaan yang dilakukan oleh Kejati Jawa Timur dengan Kejari diseluruh Jawa Timur telah menemukan titik terang, dalam beberapa kasus Kejati maupun Kejari

\footnotetext{
mediaindonesia.com. Kamis, 21 April 2011.

2 BBCIndonesia.com. 20 Mei 2011.
}

telah menetapkan tersangkanya. Rata-rata yang menjadi tersangka adalah pihak ketiga yaitu pelaksana P2SEM, baik dari lembaga pendidikan, Lembaga Swadaya Masyarakat (LSM), pondok pesantren maupun kelompok masyarakat (pokmas) penerima dana hibah dari PAK APBD Jatim 2008 tersebut.

Dari kasus-kasus tersebut muncul pertanyaan apakah tujuan program P2SEM ini benar-benar untuk program pemberdayaan masyarakat dan penanggulangan kemiskinan di jawa Timur, ataukah program ini hanya program politis semata dengan tujuan untuk mengeruk anggaran negara oleh aktor-aktor yang berkepentingan di dalam program P2SEM ini, baik yang dilakukan oleh Legislatif maupun Eksekutif. Berdasarkan hal itu, rumusan masalah yang diajukan dalam studi ini adalah: Bagaimana potensi korupsi dalam P2SEM Provinsi Jawa Timur dan Bagaimana pola serta modus korupsi Program Penanganan Sosial Ekonomi Masyarakat (P2SEM) Provinsi Jawa Timur?

\section{Pengertian Korupsi}

Menurut John Waterbury (1993:19), korupsi dapat didefinisikan dalam arti hukum yang berdasarkan norma. Di mana pada masyarakat tertentu, kedua definisi tersebut dapat berbentuk serupa (coincedent). Dalam arti hukum, korupsi adalah tingkah laku yang mengurus kepentingan diri sendiri dengan merugikan orang lain, oleh pejabat pemerintah yang langsung melanggar batas-batas hukum atas tingkah laku tersebut.

Oleh karena itu, orang yang korup menurut hukum dapat saja dianggap tindakan tidak tercela dalam koridor norma. Sebaliknya, orang bisa dinilai korup oleh standar normatif, namun justru dianggap bersih menurut hukum. Dari dua definisi ini dapat disimpulkan bahwa korupsi adalah penyalahgunaan kekuasaan dan pengaruh pemerintah untuk tujuan pribadi. 


\section{Pola dan Modus Korupsi}

Dalam tool kit Anti Korupsi yang dikembangkan oleh PBB dibawah naungan Centre of International Crime Prevention (CICP) dari UN Office Drug Control And Crime Prevention (UN-ODCCP), dipublikasikan beberapa bentuk tindakan korupsi, salah satu diantaranya yaitu: Pemberian suap/ sogok (bribery). Pemberian dalam bentuk uang, barang, fasilitas dan janji untuk melakukan atau tidak melakukan suatu perbuatan yang berakibat membawa untung terhadap diri sendiri atau pihak lain yang berhubungan dengan jabatan yang dipegangnya pada saat itu (Berek, dkk, 2006:176). Dalam konteks hukum yang berkembang, delik suap bukan merupakan persoalan baru. Dalam bahasa latin delik suap disebut briba, yang maknanya a piece of bread given to beggar (sepotong roti yang diberikan kepada pengemis). Makna ini kemudian berkembang ke makna yang bisa diartikan positif, yakni sedekah (alms), namun lebih dominan kepada gift received or given in order to influence corruptly yang oleh Prof Muladi, S.H. di pahami sebagai pemberian atau hadiah yang diterima atau diberikan dengan maksud mempengaruhi secara jahat atau korup (Wijaya, 2011:29)

Selain modus suap (Bribery) seperti yang telah dijelaskan, pos belanja bantuan yaitu dana hibah yang merupakan hasil dari penetapan kondisi darurat yang bermasalah dan menjadi isu

Tabel 1.

Pola dan Modus Korupsi

\begin{tabular}{|c|c|}
\hline POLA & MODUS \\
\hline $\begin{array}{l}\text { Pengalihan Pos } \\
\text { (peruntukan) }\end{array}$ & $\begin{array}{l}\text { - Pos Subsidi untuk kabupaten digunakan untuk pilkada Provinsi } \\
\text { (NTB) } \\
\text { - Pos dana tak tersentuh untuk Pilkada (Sleman) } \\
\text { - Pos sewa rumah (terlalu tinggi) dialihkan untuk beli kendaraan } \\
\text { dinas/motor (lampung) }\end{array}$ \\
\hline Manipulasi Anggaran & $\begin{array}{l}\text { - } \quad \text { Mark-up bukti pengeluaran } \\
\text { - } \quad \text { Perjalanan dinas fiktif/ bukti fiktif }\end{array}$ \\
\hline $\begin{array}{l}\text { Pergeseran Mata } \\
\text { anggaran }\end{array}$ & Menggeser alokasi belanja publik ke aparatur pada saat disahkan \\
\hline Publikasi Anggaran & $\begin{array}{l}\text { Pengalokasian mata anggaran baru dengan maksud, tujuan, dan } \\
\text { peruntukan yang sama dengan pos anggaran lain. Contoh : pos } \\
\text { asuransi kesehatan (PP } 110+\text { Perda), Pos pemeliharaan kesehatan } \\
\text { (Perda) } \\
\text { a. Rumah dinas } \\
\text { b. Tunjangan Pemeliharaan rumah } \\
\text { c. Sewa Rumah } \\
\text { d. Mobil baru } \\
\text { e. Biaya pemeliharaan mobil }\end{array}$ \\
\hline $\begin{array}{l}\text { Pengurangan dan } \\
\text { penghilangan sumber } \\
\text { PAD }\end{array}$ & $\begin{array}{l}\text { - Mark-down penurunan target PAD dari potensi yang ada. Contoh } \\
\text { :Parkir di kota Yogyakarta } \\
\text { - } \quad \text { Pengalihan aset daerah menjadi aset pribadi }\end{array}$ \\
\hline $\begin{array}{l}\text { Pembuatan Produk } \\
\text { hukum daerah tanpa } \\
\text { acuan produk hukum } \\
\text { yang lebih tinggi }\end{array}$ & $\begin{array}{l}\text { - Penambahan mata anggaran baru diluar Peraturan Pemerintah } \\
110 \text { yang dilegalkan dalam Perda } \\
\text { - Pengalokasian yang lebih besar dari ketentuan yang ada }\end{array}$ \\
\hline $\begin{array}{l}\text { Tender proyek } \\
\text { pembangunan }\end{array}$ & $\begin{array}{l}\text { Manipulasi proyek yang seharusnya ditenderkan oleh Pemda } \\
\text { diselesaikan dengan berita acara yang melibatkan pihak ketiga }\end{array}$ \\
\hline
\end{tabular}

Sumber : Akbarudin (2006:43) 
kunci. Pos lain yang juga mirip adalah pos belanja bantuan. Seperti halnya pos belanja tak tersangka, mekanisme akuntabilitas yang rendah membuat pos yang jumlahnya tidak sedikit ini sangat jarang bisa dikelola dan dipertanggungjawabkan dengan baik. Tabel berikut menjelaskan pola dan modus operandi korupsi yang sering muncul dalam kebijakan anggaran.

\section{Politik Anggaran}

Politik adalah konsep yang terkait dengan kekuasaan (power). Menurut Berek, dkk. (2006 :226) bahwa Politik anggaran adalah pertarungan kekuasaan yang terjadi dalam proses anggaran, mulai dari perencanaan sampai pengawasan anggaran.

Secara umum terdapat dua pandangan; pertama politik anggaran di definisikan sebagai proses kebijakan yang di dalamnya meliputi penetapan kebijakan pendapatan, belanja dan pengelolaan, maupun pengawasan dan pengendalian keuangan. Kedua, politik anggaran di definisikan sebagai "pertarungan kepentingan" diantara berbagai pihak yang berkepentingan dengan anggaran.

\section{Korupsi Politik}

Korupsi politik merupakan fenomena yang selalu terjadi melewati masa, sejarah, dan muncul dengan berbagai bentuk dan tipologi politik. Korupsi politik juga termasuk perilalu menyimpang yang berawal dari kewenangan politik yang melekat. Korupsi politik mempunyai dua pengertian. Pertama, penyalahgunaan kekuasaan yang melampaui batas kewajaran hukum oleh para pejabat atau aparatur negara. Kedua, pengutamaan kepentingan pribadi atau klien diatas kepentingan publik oleh para pejabat atau aparatur negara yang bersangkutan.

\section{Metode Penelitian}

Penelitian ini menggunakan metode penelitian studi kasus. Secara umum, studi kasus merupakan strategi yang lebih cocok bila pokok pertanyaan suatu penelitian berkenaan dengan how atau why, bila peneliti hanya memiliki sedikit peluang untuk mengontrol peristiwa-peristiwa yang akan diselidiki, dan bilamana fokus penelitiannya terletak pada fenomena kontemporer (masa kini) di dalam konteks kehidupan nyata menurut Yin (1985). Selain itu, penelitian studi kasus dapat dibedakan menjadi tiga tipe, yaitu studistudi kasus eksplanatoris, eksploratoris dan deskriptis.

\section{Deskripsi dan Implementasi dari Program Penanganan Sosial Ekonomi Masyarakat (P2SEM)}

Program Penanganan Sosial Ekonomi Masyarakat (P2SEM) di ciptakan karena adanya permasalahan kenaikan Bahan Bakar Minyak (BBM) pada pertengahan tahun 2007 yang mengakibatkan kontraksi ekonomi dan dinamika sosial. Melalui Perubahan APBD Tahun 2008, Pemerintah Provinsi Jawa Timur melakukan intervensi kebijakan penanganan masalah ekonomi dan sosial sebagai bagian dari kontribusi pemerintah daerah terhadap kebijakan yang dilakukan oleh Pemerintah Pusat. Intervensi Pemerintah Provinsi berupa dana hibah dalam bentuk Program Penanganan Sosial Ekonomi Masyarakat (P2SEM). Sedangkan sifat dan pendekatan Program Penanganan Ekonomi Sosial Masyarakat (P2SEM) lebih bersifat ad hoc program untuk memperkuat dukungan pada programprogram reguler penanganan kemiskinan.

Inti penata-usahaan kegiatan P2SEM ini adalah disalurkannya sejumlah dana hibah langsung kepada masyarakat dengan maksud agar dapat mengembangkan kemampuannya untuk menstimulasi dan mengukur potensi sumber daya internal dan sekaligus mengurangi secara bertahap ketergantungan pada sumber daya eksternal. 


\section{Mekanisme Penyaluran Program Penanganan Sosial Ekonomi Masyarakat (P2SEM)}

Mekanisme penyaluran dana P2SEM diatur dalam Peraturan Gubernur No. 72 Tahun 2008, yang merupakan Pedoman Umum Pelaksanaan Program Penanganan Ekonomi Sosial Masyarakat (P2SEM). Di dalam pedoman umum tersebut mengungkapkan bahwa Inti penata-usahaan dari P2SEM adalah Penyaluran Dana Hibah yang mana penyalurannya melalui Pokmas atau LSM.

Mekanisme penyaluran Dana Hibah P2SEM secara formal berdasarkan keterangan dari Kepala BAPEMAS Totok Soewarto adalah seperti berikut, setiap lembaga penerima hibah yang berada di konstituen anggota dewan, membuat dan mengajukan proposal yang menjadi kebutuhan di daerahnya. Proposal tersebut kemudian di rekomendasikan oleh anggota dewan setempat. Selanjutnya, proposal tersebut dikumpulkan di Sekretariat DPRD Jawa Timur (Sekwan). Tahapan selanjutnya adalah proses verifikasi proposal yang dilakukan oleh Badan Koordinasi Wilayah (BAKORWIL) tingkat daerah, kemudian diteruskan ke BAPEMAS untuk di seleksi secara administratif. Seleksi administratif meliputi alamat, tempat, pengurus lembaga, kegiatan dan akta lembaga. Pada proses ini, harus terlampir surat pengantar dari perangkat desa setempat. Setelah di seleksi, lembaga-lembaga ini kemudian diajukan ke Gubernur untuk di tetapkan. Gubernur sebagai pemegang otoritas kemudian membuat surat keputusan dan meminta Biro Keuangan untuk mencairkan anggaran.

Tetapi dalam realitas pelaksanaannya di lapangan, beberapa lembaga mengungkapkan hal yang berbeda dalam upaya mendapatkan dana hibah P2SEM. Sebagai contoh adalah yang terjadi pada lembaga Trust. Al-Khairat mengungkapkan bahwa lembaganya mendapatkan dana hibah berdasarkan informasi dari orang kepercayaan DPRD bukan dari BAPEMAS. Orang kepercayaan DPRD tersebut kemudian memberikan kesempatan untuk membuat, mengajukan proposal dan melengkapi data administrasi. Kelangkapan administrasi harus di ketahui Kepala Desa tempat kegiatan dilaksanakan, identitas lembaga dan identitas ketua. Proposal tersebut tidak di verifikasi Badan Koordinasi Wilayah (Bakorwil) tingkat daerah tetapi proposal tersebut cukup di sampaikan kepada orang kepercayaan DPRD dan menunggu informasi dana tersebut "cair".

\section{Gambar 1.}

\section{Mekanisme Penyaluran Program P2SEM}

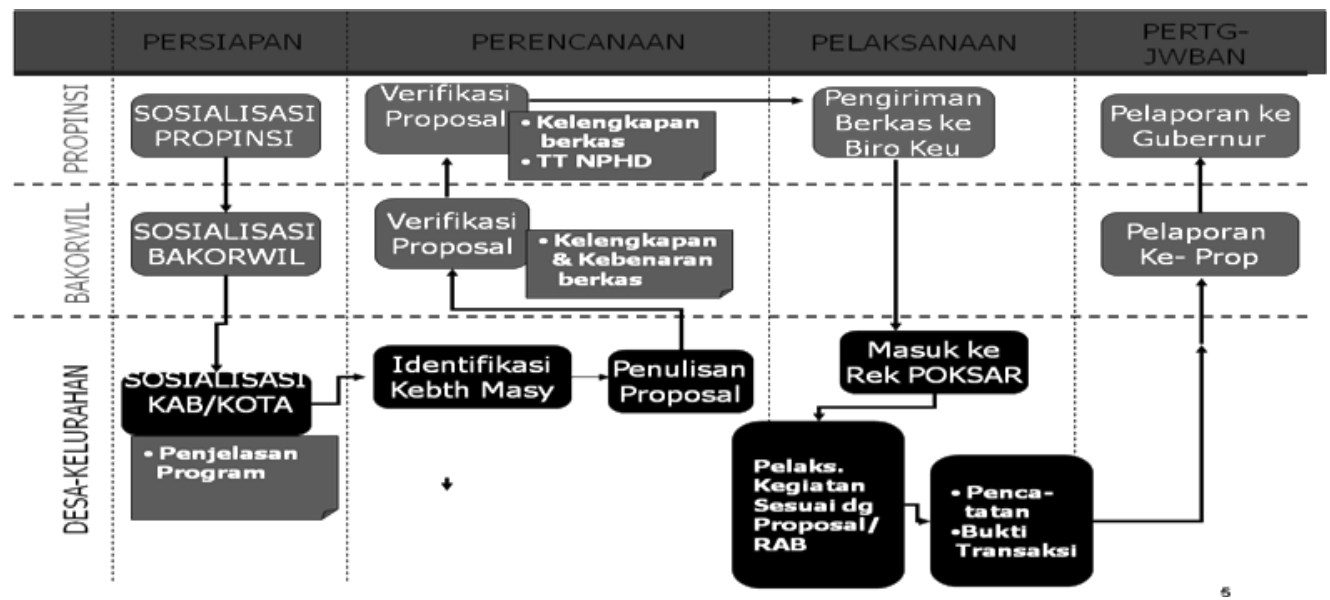

Sumber: BAPEMAS Provinsi Jawa Timur (Tahun 2008) 
Gambar 2.

Peran Calo anggaran

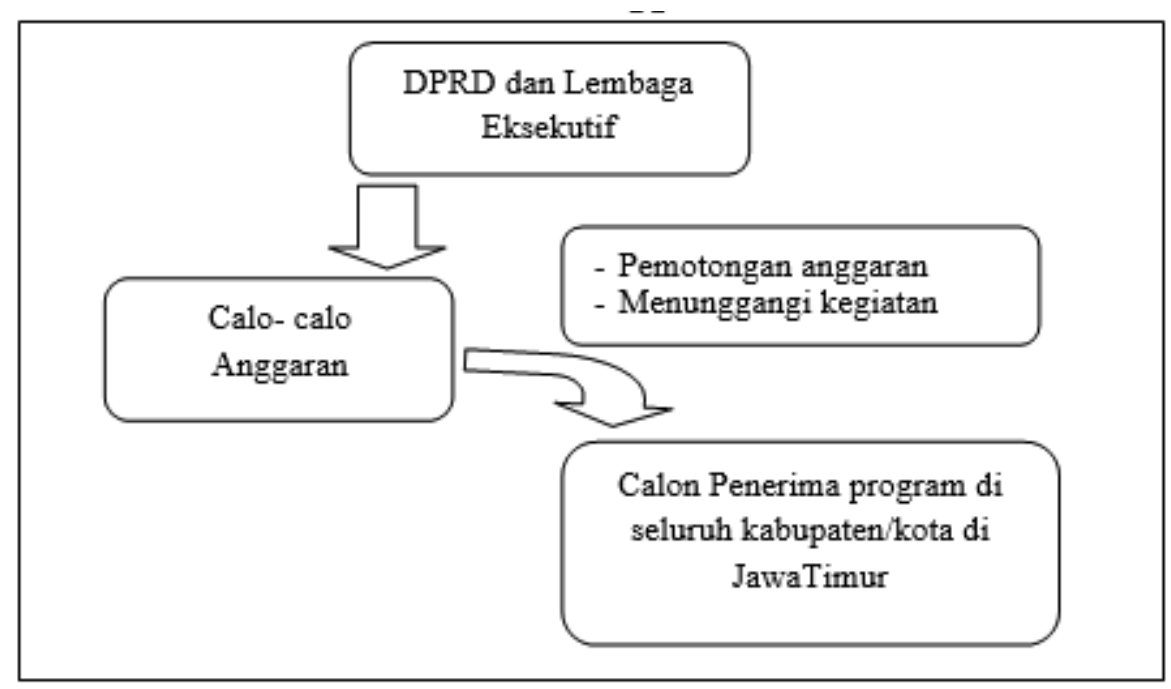

Sumber: hasil analisa penelitian

Adanya syarat seperti harus menggunakan rekomendasi dari anggota dewan padahal syarat tersebut tidak tercantum dalam pedoman umum P2SEM, mengakibatkan timbulnya calo anggaran yang merupakan relasi atau kenalan anggota dewan. Calo-calo anggaran tersebut berlomba-lomba datang ke ibukota untuk melobi anggota dewan guna mendapatkan rekomendasi sebagai syarat untuk mendapatkan dana hibah P2SEM.

Bahkan BAPEMAS sebagai leading sector penyaluran dana hibah P2SEM ini mengakui bahwa penerima dana hibah harus melalui kepercayaan anggota DPRD dengan menggunakan rekomendasi dari anggota dewan. Wawancara peneliti dengan Kepala BAPEMAS mengungkapkan bahwa penyaluran dana hibah berangkat dari kepercayaan, dari kondisi sosial ekonomi masyarakat yang sedang krisis. Jadi secara substantif yang harus bertanggung jawab adalah pemberi rekomendasi, yaitu anggota dewan. Sedang pihak BAPEMAS bertanggung jawab atas permasalahan administrasi serta bagaimana laporan penggunaan dana hibah tersebut. Karena pada prosesnya, BAPEMAS ditunjuk sebagai pelaksana penyaluran dana hibah.
Menurut Keterangan Kepala Badan Perencanaan Pembangunan Provinsi (Bappeprov) Jatim, Hadi Prasetyo, mengungkapkan bahwa rekomendasi tersebut bisa dikatakan menjadi dasar hukum proses pencairan dana. Hal ini terjadi karena dewanlah yang memiliki kewenangan untuk menilai layak atau tidaknya kelompok masyarakat (pokmas) mendapat dana hibah. Dengan rekomendasi tersebut, anggota dewan bisa menunjuk lembaga atau pokmas dan desanya untuk mendapatkan dana hibah.

Melalui rekomendasi ini, anggota DPRD berhak untuk menyalurkan anggaran APBD serta menentukan masyarakat penerima dana hibah. Padahal fungsi untuk menyalurkan anggaran dan menentukan kriteria penerima anggaran adalah wilayah dari kerja-kerja birokrasi dan itu adalah hak yang terdapat pada eksekutif.

Taufik Sholeh mengungkapkan bahwa garansi yang berupa surat rekomendasi merupakan jaminan untuk mendapatkan dana serta menjadi salah satu kepentingan politik bagi calon legislatif. Dengan menggunakan rekomendasi anggota DPRD, peluang anggota DPRD mendapatkan Kick Back dari dana P2SEM 
menjadi besar, terbukti dengan banyaknya pemotongan terhadap sejumlah LSM. Salah satu penerima dana hibah yaitu Khairul Fajar berujar:

"Pada waktu pengajuan proposal, proposal dan rekening diminta oleh Bapak Pujiarto selaku sekretaris DPRD Provinsi Jawa Timur, saya bersama teman-teman yang lain yang bersama saya sekitar 15 orang yang kemudian saya tahu dari Banyuwangi, Situbondo, dan Bondowoso disuruh menandatangani slip kosong. Ketika itu yang membawa slip kosong Bapak Pujirto, dan yang mencairkan dana juga Bapak Pujiarto. Ketika itu setelah dari Bank Jatim, kemudian kembali ke kantor sekretaris dewan bersama teman-teman lembaga lain. Kalau saya sendiri hanya diberi 20 persen dari total 200 juta dana yang tertera pada proposal. Saya hanya dikasih 40 juta."

\section{Potensi Korupsi dalam Kebijakan Publik}

Tahun 2008 merupakan "tahun politis" bagi masyarakat Jawa Timur. pada tahun ini Provinsi Jawa Timur akan menggelar Pemilihan Gubernur (Pilgub) yang harus dilaksanakan dengan sistem tiga putaran. Periode Pemilihan Gubernur ini kemudian bersambung dengan Pemilihan Umum Legislatif (Pileg) yang akan memilih para wakil rakyat di parlemen. Maka dari itu, tahun 2008 menjadi tahun politik bagi Jawa Timur, dimana semua kandidat wakil rakyat, baik DPRD/ DPR maupun DPD, calon Gubernur dan Wakil Gubernur, hingga calon Presiden dan Wakil Presiden gencar melakukan sosialisasi. Bentuk sosialisasi tersebut meliputi program, visi, misi, maupun sosialisasi figur saja.

Dalam situasi seperti ini, setiap calon pasti akan berlomba-lomba untuk mengambil simpati dari konstituen di masing-masing daerah pemilihan. Begitu pula sebaliknya, konstituen yang berada di dapil masing-masing anggota calon Legislatif akan meminta imbalan karena telah menyetorkan suaranya untuk memilihnya menjadi wakil rakyat. Begitulah budaya politik pemilihan yang nyata terjadi di sebagian besar daerah di Jawa Timur.

Kerja-kerja sosialisasi platform partai maupun visi misi kandidat dalam rangka mencari simpati publik mutlak dibutuhkan, selain sosialisasi figur atau sosialisasi rencana program. Dalam hal ini, tidak sedikit dari para kandidat tersebut "mendompleng" program-program pemerintah yang berada di bawah kewenangan kelompok dan kroninya. Bahkan tidak jarang partai politik maupun kandidat mendapatkan "anggaran gelap" untuk kampanye pemenangannya dari anggaran negara.

Praktek semacam ini telah banyak dilakukan terutama oleh calon incumbent. Baik anggota DPRD Provinsi Jawa Timur yang akan mencalonkan diri lagi dalam pemilu Legislatif, maupun mencalonkan diri dalam pemilukada. Hal serupa juga terjadi di lingkungan Eksekutif. Calon incumbent dari lingkungan Legislatif, tentunya sangat membutuhkan dana untuk mendanai konstituen di Daerah Pemilihan (dapil) masing-masing.

Di satu sisi, masyarakat telah menunjukkan antipatinya terhadap proses pemilihan. Oleh karena itu, masyarakat mulai mendesakkan hal-hal yang bersifat praktis pragmatis daripada hal yang ideal dan strategis. Dalam konteks ini, maka anggota DPRD terdesak oleh konstituen yang meminta agar para wakil rakyat mendengar aspirasinya yang bersifat praktis pragmatis. Semua itu demi tujuan keterpilihannya dalam pemilihan yang akan datang. Salah satu contohnya, adalah desakan pembangunan jembatan, renovasi masjid, pengadaan pengobatan gratis, pembagian sembako, pasar murah, dll. Tetapi permasalahannya, kewenangan anggota dewan bukan pada wilayah ini, wilayah eksekusi anggaran negara berada di lingkungan Eksekutif dengan birokrasi sebagai pelaksananya. 
Tabel 2.

Perolehan Suara dan Kursi DPRD Jawa Timur pada Pemilu 2004

\begin{tabular}{|c|l|c|c|}
\hline No & Nama Parpol & Perolehan Suara & Jumlah Kursi \\
\hline 1 & Partai Kebangkitan Bangsa (PKB) & 6.293 .314 & 31 \\
\hline 2 & Partai Demokrasi Indonesia Perjuangan (PDIP) & 4.330 .264 & 24 \\
\hline 3 & Partai Golkar (PG) & 2.676 .827 & 15 \\
\hline 4 & Partai Demokrat & 1.523 .167 & 10 \\
\hline 5 & Partai Persatuan Pembangunan (PPP) & 1.414 .733 & 8 \\
\hline 6 & Partai Amanat Nasional (PAN) & 815.233 & 6 \\
\hline 7 & Partai Keadilan Sejahtera (PKS) & 618.466 & 4 \\
\hline 8 & Partai Bulan Bintang (PBB) & 266.557 & 1 \\
\hline 9 & Partai Damai Sejahtera (PDS) & 247.413 & 1 \\
\hline & Jumlah & & 100 \\
\hline
\end{tabular}

Sumber : KPUD Jatim (2004)

\section{Dinamika Politik Menjelang Pemilu 2009}

Peta kekuatan politik DPRD Jawa Timur menjelang pemilu 2009 dapat dilihat dari perolehan suara partai politik peserta pemilu pada tahun 2004, yang diselenggarakan serentak diseluruh Indonesia pada tanggal 5 April 2004. Pelaksanaan pemilu tahun 2004 ini berdasarkan pada Undang-Undang Nomor 12 Tahun 2003 tentang Pemilu Anggota DPR, DPD, dan DPRD. Pemilu ini diikuti oleh 24 partai politik peserta pemilu dan banyak sekali peserta perorangan sebagai calon anggota DPD.

Dari 24 partai politik peserta Pemilu 2004, hanya ada 9 partai politik yang berhasil mendapatkan kursi di DPRD Jawa Timur periode 2004-2009. Dengan urutan teratas ditempati oleh Partai Kebangkitan Bangsa (PKB), Partai Demokrasi Indonesia Perjuangan (PDIP) diurutan kedua, dan Partai Golkar berada pada posisi ketiga pemenang pemilu. Tidak heran apabila Partai Kebangkitan Bangsa sangat mendominasi perolehan suara di Jawa Timur, karena basis pemilih di Jawa Timur memiliki kedekatan latar belakang dan kedekatan ideologis dengan PKB.

Kekuatan PKB tersebar di daerah tapal kuda, Madura dan wilayah pantura. Kondisi ini tidak bisa dilepaskan dari daya tarik figur seorang $\mathrm{KH}$. Abdurahman Wahid atau lebih dikenal dengan Gus Dur. Cucu pendiri
Nahdlatul Ulama' ini sangat menentukan kemenangan PKB di Jawa Timur. Selain itu, sebagai partai yang didirikan oleh organisasi Islam terbesar di Indonesia, PKB mendapat dukungan besar dari para Kiai pengasuh pondok pesantren di Indonesia, dan basis Kiai - Kiai besar pendukung PKB itu berada di Jawa Timur.

Sebagian besar calon anggota DPRD dari PKB merupakan kalangan pesantren atau para pengurus NU di wilayah. Mereka adalah orangorang yang memiliki daya tarik tersendiri di mata pemilih pada daerah pemilihannya masing-masing. Keterlibatan para calon anggota DPRD dari PKB dalam aktivitas kemasyarakatan bukanlah sesuatu yang instan, akan tetapi sudah terbangun sejak lama melalui organisasi kemasyarakatan NU. Sehingga, tidak mengherankan apabila PKB mampu menempatkan kadernya sebanyak 31 orang sebagai anggota DPRD Jawa Timur periode 2004 - 2009 dari hasil Pemilu tahun 2004. Tidak hanya itu, PKB juga mampu mengantarkan salah satu kadernya menjadi pimpinan DPRD Jawa Timur, sebagai ketua DPRD Jawa Timur periode 2004 - 2009, yaitu Fathorrasjid. Sebagai pemilik suara mayoritas di DPRD Jawa Timur, PKB mampu memainkan peranan signifikan dalam aktivitas ke-legislatif-an, baik dalam perumusan kebijakan, perumusan anggaran, hingga pengawasan. 


\section{Konflik Partai Kebangkitan Bangsa (PKB)}

Perkembangan politik selanjutnya, menggiring PKB kepinggiran kekuasaan, fenomena yang terjadi ditingkat nasional (baca:DPP PKB) berimbas pada peta kekuatan PKB di Jawa Timur. Sehingga secara de facto, PKB tidak mampu lagi mempertahankan dominasi politiknya di DPRD Jawa Timur, walaupun secara de jure, PKB masih merupakan partai dengan perolehan suara terbesar di Jawa Timur serta merupakan partai dengan perolehan kursi terbanyak di DPRD Jawa Timur. Konflik yang mendera internal kepengurusan PKB juga berimbas pada level kader PKB di daerah. Munculnya faksi di tubuh PKB menyebabkan terbelahnya kekuatan PKB di DPRD Jawa Timur.

Berawal dari pelaksanaan Muktamar II Partai Kebangkitan Bangsa (PKB) yang dilaksanakan di Semarang, PKB harus merelakan beberapa kadernya untuk keluar dan membentuk partai baru yang kemudian menjadi salah satu peserta pemilu tahun 2009, yaitu Partai Kebangkitan Nasional Ulama' (PKNU). Awal semua kekisruhan di arena muktamar adalah peristiwa pemecatan terhadap Ketua Umum Tanfidz PKB Alwi Shihab, dan Syaifullah Yusuf sebagai sekretaris Umum Dewan Tanfidz PKB oleh Ketua Dewan Syura PKB, KH. Abdurrahman Wahid. Alasannya karena Alwi Shihab dan Syaifullah Yusuf telah menerima tawaran menjadi salah satu Menteri Kabinet Indonesia Bersatu I pimpinan Presiden Susilo Bambang Yudoyono.

Konflik yang mengarah pada perpecahan partai ini mencapai puncaknya di arena muktamar PKB II di Semarang. Meskipun demikian, hasil Muktamar II PKB di Semarang yang berlangsung sejak tanggal 16 hingga tanggal 18 April 2005 berhasil menetapkan Gus Dur sebagai Ketua Dewan Syuro dan Abdul Muhaimin Iskandar sebagai Ketua Umum Tanfidz untuk periode 2005-2010.
Forum pleno yang telah sepihak menyatakan aklamasi terhadap Gus Dur itu menimbulkan protes dan ancaman walkout dari beberapa peserta muktamar. Aksi ini dimotori oleh Ketua DPW PKB Jatim Choirul Anam dan mantan Ketua Umum PKB Alwi Shihab, keduanya menganggap penetapan Gus Dur sebagai Ketua Dewan Syuro serta pelaksanaan muktamar secara keseluruhan dinilai tidak sah alias cacat hukum. Salah satunya, karena tidak melibatkan Ketua Umum Alwi Shihab dan Sekretaris Jenderal Saifullah Yusuf yang diberhentikan hanya oleh pleno DPP dan bukan oleh muktamar.

Namun, kelompok Gus Dur - Muhaimin tidak mengindahkan ketidak-puasan yang dilontarkan oleh kelompok Alwi - Anam yang didukung oleh beberapa Kiai sepuh PKB, hingga akhirnya kelompok Alwi Anam melakukan gugatan secara hukum terhadap kelompok Gus Dur. Namun, hingga putusan pengadilan tinggi keluar, gugatan Alwi-Anam tetap dikalahkan oleh pengadilan dan kelompok Gus Dur-Muhaimin adalah pengurus yang sah secara hukum dan diakui oleh pemerintah.

Dengan kekalahan pada proses hukum di pengadilan, kekecewaan kelompok AlwiAnam dan beberapa Kiai sepuh PKB dan NU akhirnya menyebabkan kelompok ini berikhtiar lain dengan membidani lahirnya partai baru. Perpecahan tersebut akhirnya semakin nyata dan kelompok Alwi-Anam bersama beberapa kiai mendeklarasikan sebuah partai bernama Partai Kebangkitan Nasional Ulama (PKNU). Partai ini merupakan partai yang didirikan oleh para kiai Nahdlatul Ulama (NU) yang berseberangan dengan $\mathrm{KH}$ Abdurrahman Wahid (Gus Dur). Selain itu, pendirian PKNU juga untuk mengoreksi PKB sebagai parpol yang dilahirkan PBNU, yang dinilai telah menyimpang jauh dari harapan warga NU.

Dalam praktiknya, PKNU bukan saja menjadi wadah ulama non-kubu Gus Dur, tapi juga politisi PKB yang keluar akibat 
konflik internal. Dua tokoh sentral di PKNU adalah Alwi Shihab dan juga Choirul Anam, dengan modal para Kiai Khos yang memiliki pengaruh luas bagi warga NU. PKNU bahkan mampu menarik beberapa anggota DPRD di daerah untuk keluar dari PKB, termasuk beberapa orang anggota DPRD Jawa Timur. Beberapa Anggota DPRD Jawa Timur yang semula berasal dari Partai Kebangkitan Bangsa (PKB) menyeberang ke Partai Kebangkitan Nahdatul Ulama (PKNU) salah satunya adalah Fathorrasjid yang saat itu masih menjabat sebagai Ketua DPRD Jawa Timur 2004-2009. Tidak hanya Fathorrasjid, beberapa anggota fraksi PKB diDPRDJawa Timuryang memegang posisi strategis secara diam-diam pindah ke PKNU mengikuti jejak Choirul Anam. Pada perkembangannya, beberapa kebijakan yang dibuat oleh DPRD secara internal maupun eksternal sangat menguntungkan bagi PKNU, karena sifat dominasi yang dahulu dimiliki PKB lantas beralih menjadi milik PKNU.

Strategi Pergantian Antar Waktu (PAW) yang dilakukan PKB terhadap beberapa anggota yang menyeberang ke PKNU pada prosesnya banyak menuai kegagalan dikarenakan posisi pimpinan DPRD sangat menentukan proses PAW dapat berjalan atau tidak. Hal ini dikarenakan Ketua DPRD Jawa Timur dijabat oleh Fathorrasjid yang sudah menjadi bagian dari PKNU, menjadi salah satu orang yang diusulkan diganti oleh PKB. Salah satu kebijakan bersama di lingkungan DPRD Jawa Timur bersama dengan Pemerintah Provinsi Jawa Timuryang sangat menguntungkan PKNU adalah penyaluran Program Penanggulangan Ekonomi Masyarakat (P2SEM).

\section{Tipologi Political Bribery}

Salah satu tipe korupsi dalam perspektif ilmu kriminologi adalah political bribery. Korupsi tipe ini dapat didefinisikan sebagai pemberian suap atau janji pada lembaga politik untuk kepentingan tertentu, termasuk di dalamnya adalah kekuasaan Legislatif sebagai badan pembentuk undang-undang (Madril, dkk. 2008:60). Secara politis, badan tersebut dikendalikan oleh kepentingan tertentu. Hal ini disebabkan oleh besarnya dana yang dikeluarkan pada masa pemilihan umum. Oleh sebab itu, praktek-praktek korupsi sangat mudah sekali terjadi di lingkungan gedung parlemen, baik berdasarkan motivasi individu anggota DPR, maupun dorongan dari partai induknya.

Besarnya dana yang dibutuhkan partai politik untuk membiayai kegiatan parpol seharihari hingga upaya-upaya mempertahankan tingkat elektabilitas partai dimata konstituen "memaksa" kader-kader parpol di parlemen maupun di lingkungan Eksekutif untuk menyisihkan sebagian anggaran negara untuk kepentingan parpol.

Hal serupa terjadi di lingkungan DPRD Jawa Timur yang notabene anggotanya merupakan anggota partai politik. Lembaga Legislatif daerah ini dimanfaatkan untuk melakukan langkah-langkah taktis dan praktis demi memenuhi tuntutan konstituen partai. Pembicaraan pada Rapat Panitia Anggaran (Panggar) tahun 2008 yang melahirkan perubahan anggaran keuangan (PAK) tahun 2008, memutuskan beberapa hal, diantaranya anggaran dana hibah daerah. Kebijakan tersebut merupakan kesepakatan bersama antara Legislatif yaitu DPRD Jawa Timur bersama Gubernur Jawa Timur. Kebijakan ini kemudian dituangkan dalam Peraturan Daerah (Perda) Nomor 6 tahun 2008 tentang Perubahan Anggaran Keuangan (PAK) Anggaran Pendapatan Belanja Daerah Jawa Timur tahun anggaran 2008.

Dalam keadaan terdesak oleh kebutuhan konstituen serta didasari oleh keingingan kuat untuk berkuasa kembali, para anggota DPRD merasa harus memenuhi kebutuhan konstituennya dalam waktu dekat, dan terlibat langsung dalam penyaluran bantuan. Oleh karenaitulah, anggotaDPRDmelakukandesakan kepada Eksekutif untuk memformulasikan 
sebuah proyek pemberdayaan terhadap masyarakat melalui anggaran PAK tahun 2008. Dalam PAK tahun 2008, pada pasal 2 ayat 4 item (a) tentang pendapatan dana hibah, serta pasal 3 ayat 2 item (d) tentang belanja hibah yang semula Rp. 998,216,500,000 bertambah Rp. 93,427,200,000 sehingga total berjumlah Rp. 1,092,143,700,000.

Melalui item dana hibah inilah, proyek bernama Program Penanggulangan Sosial Ekonomi Masyarakat (P2SEM) lahir, sedangkan leading sector proyek ini adalah Badan Pemberdayaan Masyarakat (BAPEMAS) Provinsi Jawa Timur. Dalam implementasinya, proyek ini, secara tidak langsung telah melibatkan anggota Legislatif. Maka, sementara dapat disimpulkan bahwa proyek pemberdayaan masyarakat yang lahir dari sebuah kebijakan yang disepakati bersama-sama antara Eksekutif dan Legislatif tersebut merupakan produk kebijakan kolutifkoruptif. Bahwa, sejatinya proyek ini hanya dimaksudkan untuk kepentingan pembiayaan atau ongkos politik tertentu, yaitu memenuhi tuntutan konstituen atau calon pemilih, dengan harapan penerima program dapat memberikan dukungan dan pilihannya dalam pemilu mendatang pada pemberi program atau pemberi rekomendasi program. Tindakan ini yang selanjutnya dapat dikategorikan sebagai political bribery, dimana pembuat kebijakan telah mengambil keuntungan secara materi dari kebijakan yang dibuatnya.

Seperti kasus yang menimpa Khairul Fajar, salah satu terdakwa kasus P2SEM yang divonis bersalah oleh Pengadilan Negeri Jember, bahwa dia divonis bersalah oleh Pengadilan Negeri Jember dengan pidana 1,8 Tahun penjara. Status Khairul Fajar dalam P2SEM merupakan pihak ketiga, Khairul Fajar adalah ketua Panitia Rehabilitasi Gedung Pondok Pesantren AlAmin. Secara singkat, Khairul bercerita tentang kronologis pengajuan proposal dana hibah P2SEM yang diajukannnya (lihat wawancara sebelumnya). Pengakuan itu merupakan salah satu bentuk dari political bribery. Namun dalam konteks ini, yang dimaksud dengan penyuapan justru dipaksakan atau lebih tepatnya pemotongan anggaran. Kewenangan memberikan rekomendasi oleh anggota DPRD pada pihak ketiga sebagai pelaksana program, merupakan salah satu strategi anggota DPRD untuk dapak melakukan pemotongan anggaran kegiatan yang diterima oleh pihak ketiga, yaitu kelompok masyarakat, LSM, perguruan tinggi, maupun lembaga-lembaga pendidikan.

Akhir dari semua tahapan Pemilihan Kepala Daerah Jawa Timur, setelah melalui pemilihan dua putaran ditambah satu putaran untuk mengulang pemilihan di Madura, berdasarkan perolehan suara terbanyak pemilihan Kepala Daerah dimenangkan oleh pasangan Soekarwo dan wakilnya Saifullah Yusuf (Karsa) yang di usung oleh Partai Demokrat dan Partai Amanat Nasional (PAN). Calon Kepala Daerah pasangan dapat dikatakan sebagai incumbent. Sebab, pada era sebelumnya Soekarwo menjabat sebagai Sekretaris Daerah Provinsi (SEKDAPROP) Jawa Timur.

Jadi, berdasarkan hasil pemilihan kepala daerah tersebut, tidak menutup kemungkinan bahwa dana hibah P2SEM yang dikucurkan menjelang Pemilu kepala daerah tahun 2008 juga di pergunakan oleh Eksekutif yakni pihak-pihak yang memiliki akses terhadap anggaran untuk pemenangan salah satu kandidat Gubernur dan Wakil Gubernur. Pemanfaatan program P2SEM tersebut dapat dilakukan dengan menggunakan cara pemotongan seperti dilakukan anggota DPRD Jawa Timur, maupun dengan cara mendompleng kegiatan P2SEM.

\section{Kebijakan Koruptif}

Lahirnya Program Penanganan Sosial Ekonomi Masyarakat (P2SEM) tahun 2008 Provinsi Jawa Timur didasarkan pada Peraturan Daerah (Perda) Provinsi Jawa Timur Nomor 6 tahun 2008 tentang Perubahan Anggaran Keuangan (PAK), Anggaran Pendapatan, dan Belanja Daerah Provinsi Jawa Timur 
tahun anggaran 2008. Peraturan daerah ini merupakan kebijakan bersama antara DPRD Provinsi Jawa Timur bersama Gubernur Jawa Timur.

Adanya mekanisme perubahan APBD ini seringkali menjadi atau dijadikan peluang untuk melakukan perubahan belanja-belanja di luar ketetapan APBD. Padahal perubahan APBD memerlukan alasan yang cukup kuat yakni berubahnya beberapa asumsi yang dijadikan dasar dalam penetapan APBD, termasuk didalamnya terjadinya peristiwa-peristiwa diluar dugaan atau peristiwa-peristiwa alam.

Perubahan APBD tidak dapat dilakukan dengan mudah tanpa didasari oleh rasionalisasi dan landasan yuridis yang kuat. Ada beberapa hal yang harus dipenuhi dalam melakukan perubahan APBD, seperti dijelaskan dalam modul pendidikan politik anggaran yang ditulis Berek, dkk (2006:177) bahwa perubahan APBD dapat dilakukan apabila terjadi hal-hal berikut ini:

1. Keadaan darurat dengan Kriteria berikut ini.
a. Bukan merupakan kegiatan normal dari aktivitas Pemerintah Daerah dan tidak dapat di prediksi sebelumnya
b. Tidak diharapkan terjadi secara berulang
c. Berada di luar kendali dan pengaruh Pemerintah Daerah
d. Memiliki dampak yang signifikan terhadap anggaran dalam rangka pemulihan yang di sebabkan oleh keadaan darurat

2. Perkembangan yang tidak sesuai dengan asumsi kebijakan umum APBD

3. Keadaan yang menyebabkan harus dilakukan pergeseran anggaran antar unit organisasi, antar kegiatan, dan antar jenis belanja.

4. Keadaan yang menyebabkan sisa lebih perhitungan anggaran tahun sebelumnya harus digunakan untuk pembiayaan dalam tahun anggaran berjalan.
Peraturan Daerah No. 6 tahun 2008 mengenai Perubahan Anggaran Keuangan (PAK) APBD Jatim di latar belakangi karena perkembangan yang tidak sesuai dengan asumsi kebijakan APBD akibat dari kenaikan BBM pada tahun 2008. Untuk mengantisipasi adanya kontraksi sosial ditengah-tengah masyarakat Jawa Timur, pemerintah perlu melakukan intervensi kebijakan. Salah satu poin perubahan dalam PAK tahun 2008 yang dilakukan Pemerintah Provinsi Jawa Timur (Pemprov Jatim) bersama dengan DPRD Jawa Timur adalah persetujuan adanya penambahan anggaran dana hibah daerah dalam Anggaran Pendapatan dan Belanja Daerah (APBD) tahun 2008.

Perubahan anggaran menjadi atau dijadikan salah satu pintu masuk untuk melakukan tindakan korupsi oleh beberapa pihak yang berkepentingan di lembaga Legislatif maupun Eksekutif. Meski demikian, perubahan anggaran keuangan tetap memiliki landasan atau pembenar secara yuridis.

\section{Pola dan Modus Korupsi P2SEM \\ Calo Anggaran}

Calo adalah pihak ketiga yang menjadi penghubung antara pihak pertama, dalam hal ini adalah pemerintah Provinsi Jawa Timur sebagai leading sector program, dengan pihak kedua, dalam konteks ini adalah pelaksana program. Calo, atau dapat disebut juga sebagai makelar menjadi salah satu rantai penghubung dalam implementasi P2SEM. Adanya calo atau makelar disini meniscayakan adanya fee, baik imbalan dari pihak pertama, pihak kedua, atau bahkan dari kedua belah pihak. Dari sinilah, atas hadirnya jasa calo atau makelar menjadi salah satu modus kebocoran anggaran program.

\section{Surat Sakti}

Selain praktek percalonan, dalam pelaksanaan P2SEM ada "surat sakti" yang 
harus dilampirkan dalam setiap proposal yang diajukan oleh masyarakat. Meski dalam peraturan umum pelaksanaan P2SEM tidak mensyaratkan adanya "surat sakti", namun dalam realitanya, penyaluran dana hibah ini disertai persyaratan adanya surat rekomendasi dari anggota DPRD Jawa Timur. Adanya syarat yang tidak lazim berupa surat rekomendasi dari anggota DPRD Provinsi Jawa Timur dalam penyaluran program P2SEM menyisakan banyak permasalahan. Padahal syarat tersebut tidak tercantum dalam Pedoman Umum Program P2SEM yang tertuang dalam Peraturan Gubernur Jawa Timur Nomor 72 tahun 2008. Bahkan, peraturan ini sama sekali tidak menyebutkan lembaga Legislatif atau DPRD Jawa Timur sebagai salah satu mata rantai penyaluran dana hibah daerah ini.

\section{Praktek Suap (Bribery)}

Menurut Wakil Ketua KPK, M Jasin, mengungkapkan bahwa pada umumnya praktek suap (Bribery) terjadi karena inisiatif dari kedua belah pihak yakni pemberi dan penerima layanan. Dalam konteks P2SEM, calocalo anggaran mempunyai peranan sebagai pemberi garansi disetujuinya usulan kegiatan P2SEM. Sedangkan penerima layanan yakni pelaksana kegiatan dari anggaran dana hibah P2SEM merupakan kelompok masyarakat di daerah-daerah maupun beberapa perguruan tinggi di Jawa Timur yang mendapatkan jaminan disetujuinya usulan dengan pemberian surat rekomendasi dari anggota DPRD Jawa Timur.

\section{Mark Up Anggaran}

Modus korupsi berikutnya setelah suap (Bribery) adalah melakukan mark up anggaran, baik dalam usulan program maupun dalam laporan pertanggungjawaban, sehingga implementasi anggaran 50 persen dari pagu awal dalam laporan pertanggungjawaban tetap dilaporkan 100 persen dari pagu anggaran proposal. Praktek ini sudah sangat popular dilakukan untuk menaikkan anggaran. Cara ini dilakukan dengan menaikkan harga barang atau jasa dari harga aslinya.

\section{Pelaksana/ Kegiatan Fiktif}

Modus lain yang ditemukan dalam kasus korupsi P2SEM adalah ditemukannya lembaga fiktif atau kegiatan fiktif. Modus ini diketahui dalam pemeriksaan di Kejaksaan Tinggi Jawa Timur terhadap beberapa tersangka penerima dana hibah. Dalam proses pemeriksaan ditemukan adanya beberapa pelaksana program yang tidak melaksanakan kegiatan atau bahkan lembaga yang digunakan juga lembaga "awu-awu" atau lembaga "dadakan". Pola ini dilakukan oleh para penerima dana hibah dengan cara mengajukan proposal kegiatan. Namun setelah dana tersebut diterima melalui rekening bank, dana tersebut tidak pernah direalisasikan untuk kegiatan seperti diusulkan.

\section{Kesimpulan}

Program Penanganan Sosial Ekonomi Masyarakat(P2SEM) dalam prakteknya menjadi program yang ditunggangi oleh kepentingan politik praktis para elit-elit pembuat kebijakan, baik dari lembaga Legislatif maupun lembaga Eksekutif. Salah satu faktor sebagai penyebab korupsi adalah aspek perundangan yang memberikan peluang bagi para aktor pembuat kebijakan untuk melanggengkan korupsi.

Berdasarkan kesimpulan diatas maka rekomendasi yang diajukan adalah melakukan revisi terhadap peraturan perundangan yang berpotensi melanggengkan korupsi. Selain itu, perlu dilakukan pengaturan kembali terhadap kewenangan yang dimiliki Legislatif, dengan mengurangi kewenangan DPRD yang terlalu besar. Sehingga, peluang Legislatif untuk melakukan bargaining position dengan Eksekutif yang mengarah pada kompromi politif, kolusi - koruptif akan dapat dihindarkan. Disamping 
Nian Riawati, Potensi Korupsi dalam Kebijakan Publik Studi Kasus Korupsi Program Penanganan Sosial Ekonomi Masyarakat di Provinsi Jawa Timur

itu, perlu adanya pengaturan yang lebih ketat dan tegas terhadap penggunaan dana hibah serta pembatasan penggunaan dana hibah pada hal-hal yang benar-benar mendesak, terukur serta dapat dipertanggung-jawabkan. Terakhir, tidak harus selalu melibatkan anggota Legislatif dalam setiap pelaksanaan program kegiatan baik pelibatan dalam bentuk pemberian rekomendasi oleh anggota Legislatif terhadap pelaksana program maupun jaminanjaminan lainnya.

\section{Daftar Pustaka}

\section{Buku}

AbdulWahab, Solichin.(1991). Analisis Kebijakan: Dari Formulasi Ke Implementasi Kebijakan Negara. Jakarta: Binarupa Aksara.

Akbarudin, Arif. (2006). Menjaring Uang Rakyat: Ragam Advokasi Anggaran di Indonesia. Yogyakarta: Institute for Development and Economic Analysis (IDEA).

Alatas, Syed Hussein. (1999). Corruption and The Destiny of Asia. Kuala Lumpur: Prentice Hall.

Albab, Ulul. (2009). A to Z Korupsi: Menumbuhkembangkan Semangat Anti Korupsi. Surabaya: Jaring Pena.

Arikunto, Suharsimi. (2006). ProsedurPenelitian, Suatu pendekatan dan praktek. Jakarta: Rineke cipta.

Berek, Fridolin. (2006). Politik Anggaran Bagi Warga. Bandung: Bandung Institute of Government Studies.

Dunn, William N. (2000). PengantarAnalisis Kebijakan Publik. Yogyakarta: Gadjah Mada University.

Hikmat, R. Harry. (2004). Strategi Pemberdayaan Masyarakat. Bandung: Penerbit Humaniora.

Komorotomo, Wahyudi \& Agus, Erwan. (2005). Anggaran Berbasis Kinerja; Konsep dan Aplikasinya, Yogyakarta: MAP UGM.

Madril, Oce, dkk. (2008). Menyelamatkan uang rakyat: Kajian Akademik Peraturan Pemerintah
Nomor 37 Tahun 2006. Yogyakarta: Pusat Kajian Anti Korupsi (PuKAT) Fakultas Hukum Universitas Gajah Mada.

Moeljanto. (2002). Azas-Azas Hukum Pidana. Jakarta: Bina Isnsani.

Parsons, Wayne. (2006). Public Policy, Pengantar Teori dan Praktik Analisis Kebijakan. Jakarta : Prenada Media Group

Putra, Fadilah. (2001). Paradigma Kritis dalam

Studi Kebijakan Publik. Yogyakarta: Pustaka Pelajar.

Soekanto, Soejono, dkk. (1981). Kriminologi Suatu Pengantar. Jakarta: Ghalia Indonesia.

Subarsono, AG. (2008). Analisis Kebijakan Publik, (Konsep, Teori dan Aplikasi). Yogyakarta: Pustaka Pelajar.

Surbakti, Ramlan. (1984). Dasar-Dasar Ilmu Politik. Surabaya: Unair Press.

Waterbury, Jhon. (1973). Endemic And Planned Corruption In A Monarchical Regime World Politic. Princetor University Press.

Wibawa, Samodra. (1994). Kebijakan Publik: Proses dan Analisis. Jakarta: Penerbit Intermedia.

Wijaya, Firman. (2010). Delik Penyalahgunaan Jabatan Dan Suap Dalam Praktek. Jakarta: Penaku.

Yin, Robert K. (1985). Case Study Research Desain and Methods. Beverly Hills London New Delhi : Sage Publications.

Zamrony, dkk. (2009). Buku Panduan Kuliah Kerja Nyata, Pemberdayaan Masyarakat Pengguna Pengadilan. Yogyakarta: Pukat Korupsi UGM.

\section{Jurnal dan Karya Ilmiah}

Abdullah, Syukriy \& Asmara, Jhon Andra. (2007). Perilaku Oportunistik Legislatif Dalam Penganggaran Daerah Bukti Empiris Atas Aplikasi Agency Theory Di Sektor Publik. Jurnal Riset Akuntansi Indonesia. Vol.10 No.1 Januari 2007

Faidy, Ach, Suja'ie. (2011). Amputasi Korupsi di Tubuh Partai Politik. Koran Tempo.

Halim, Abdul \&Abdullah, Syukriy Abdullah. (2009). Hubungan dan Masalah Keagenan di 
Pemerintah Daerah: Sebuah Peluang Penelitian Anggaran dan Akuntansi

Purbathin Hadi, Agus. Tinjauan Terhadap Berbagai Program Pemberdayaan Masyarakat di Indonesia. Yayasan Agribisnis/Pusat Pengembangan Masyarakat Agrikarya (PPMA)

\section{Perundang-undangan}

Undang-Undang No. 17 Tahun 2003

Undang-Undang No. 20 Tahun 2001

Undang-Undang Nomor 31 Tahun 1999
Peraturan Pemerintah No. 58 Tahun 2005

Peraturan Menteri Dalam Negeri No. 30 Tahun 2007

Peraturan Daerah (Perda) Pemerintah Provinsi Jawa Timur No. 6 Tahun 2008

Peraturan Gubernur (Pergub) Jawa Timur No. 72 Tahun 2008

Tool Kit Anti Korupsi yang dikembangkan oleh PBB dibawah naungan Centre of International Crime Prevention (CICP) dari UN Office Drug Control And Crime Prevention (UN-ODCCP) 